\title{
The Impact of Work Autonomy and Organizational Commitment on Organizational Communication
}

\author{
Olha Ilyash', Osman Yildirim, ${ }^{2, *}$, Selcuk Capuk ${ }^{3}$, Nevin Bozgul ${ }^{2}$ \\ ${ }^{1}$ International University of Finance, Kiev, Ukraine \\ ${ }^{2}$ Istanbul Arel University, Istanbul, Turkey \\ ${ }^{3}$ Nisantasi University, Istanbul, Turkey
}

\begin{abstract}
The aim of this study was to explore the impact of work autonomy and organizational commitment on organizational communication. To this end, a questionnaire was designed by using the scales of work autonomy and organizational commitment to organizational communication. in this paper, the impact of work autonomy and organizational commitment on organizational communication was studied considering the perceptions of health employees. The results showed a high-reliability level $(>.80)$ of organizational communication and organizational commitment scales which were applied in the research. Sub-dimensions of the organizational commitment scale, namely, normative commitment, affective commitment, continuance commitment, revealed a high-reliability values of dimensions. As a result of the applied structural equation model, work autonomy variable positively affects the organizational commitment variable. It was found that the increase in the organizational commitment and work autonomy variables affect the increase of the work autonomy variable. Confirmatory factor analysis of research scales was found to be meaningful because the model test values were $\mathrm{x}^{2}, \mathrm{x}^{2} / \mathrm{df}$. Further, the fit index values GFI, CFI, SRMR, RMSEA were found to be within acceptable limits. In this model, work autonomy variable could be explained by $52 \%$ and organizational communication variable by $26 \%$. In the designed model, Organizational Communication variable adversely affects the organizational commitment variable and work autonomy variable adversely affects it. The increase in the organizational commitment and work autonomy variables affect the organizational communication variable.
\end{abstract}

\section{Keywords:}

Work Autonomy, Organizational Commitment, Organizational Communication 


\section{Introduction}

Today, the top executives of the organizations carefully investigate the organizational behaviour variables in order to achieve the organizational goals. For this reason, the most effective organizational behaviour variables such as organizational variables, namely, work autonomy, organizational communication and organizational commitment were chosen.

\section{Work Autonomy}

Work autonomy is the discretion and freedom of discretion granted to the employee during the work (Hackman and Oldham, 1976). Autonomy is defined by managers as an important part of business design. It supports the creativity of employees and enables them to take risks while applying their own ideas (Davis, 1994). Business autonomy is the degree of freedom that an employee has when planning and working in his / her work (Morgeson, Delaney-Klinger, \& Hemingway, 2005). In other words, it can be expressed as the right of choice and freedom of the person doing the work (Brey, 1999).

Work autonomy, which is included in Hackman and Oldham (1976)'s model of business autonomy, is one of the most important initiatives in designing highly motivated professions. Autonomous employees have the freedom to add value to the work they are doing by using their own training and experience in terms of the duration of their work, the content of the work and the evaluation. However, since they will work with other team members, autonomy is not a complete independence (Dee, Henkin, \& Chen, 2000). The important point is that the concepts of autonomy and control are not confused. Autonomy is independence but it should be controllable. The evaluation of the project, working instruments, content and duration of the work, must be controllable (Schwalbe, 1985).

Autonomy makes an employee feels capable and creative. Thus, autonomy, motivation and performance-enhancing performance are effective in organizations that work autonomy is achieved (Gellatly and Irving, 2001). If individuals feel themselves under pressure as they work, they may not be able to provide stability in their performance. Their performance and their pleasure will be shortterm (Vansteenkiste, Simons, Lens, Sheldon, \& Deci, 2004).

In this study, the scale used by Ilardi, Leone, Kasser and Ryan (1993) was used to measure the perception of work autonomy. As the basic indicators of business autonomy, the degree of freedom of the employees, independent behavior, use of discretion or taking risks while applying their own plans can be shown (Hackman and Oldham, 1976; Davis, 1994). Business autonomy is an important psychological variable that contributes to employee's performance. In other words, the employee with autonomy in his / her work will show a better performance (Saragih, 2011).

\section{Organizational Communication}

Communication is also one of the basic tools that managers use in their organizational environment (Koçel, 2001). It is also very important for the employees to understand and adopt the objectives of the organization, to be motivated and to have knowledge about management. To the extent that this can be achieved, the more information about the organization's rules, goals and objectives, the easier and faster the organization will be able to reach the target of the organization (Vulnerable and Committed, 2007). Communication has a central important role because it is vital for every organization (Md Nordin, Halib, \& Ghazali, 2011). 


\section{Organizational Commitment}

The concept of organizational commitment was first devised by Whyte in 1956, and later developed by many researchers such as Mowday, Steers, Allen, Meyer, Becker, especially Porter (Morrow and McElroy, 1986).

When the literature on organizational commitment is examined, it is seen that many definitions have been made, and the most prominent, generally accepted definitions are given here. We might mention such examples as a person's desire to integrate with the organization (Morris ,Lydka, \& O'Creevy, 1993), loyalty to organizational identity (Leong, Furnham, \& Cooper, 1996), the degree of identification and integration that he/she feels towards the organization (Brewer, 1996) or willingness to remain in the organization (Davis and Newstrom., 1989).

In their study, Meyer, Allen and Smith examined the loyalty to the organization in three dimensions: (1) affective commitment, (2) continuance commitment, and (3) normative commitment (Speetor, 1996). Affective commitment expresses the love and identification between the employee and the organization while the continuance commitment refers to the costs of leaving the organization and the normative commitment expresses the responsibility of staying in the organization.

Emotional commitment is the emotional commitment of employees to the institution they work with. Employees are willing to accept the goals and values of the organization and continue staying voluntarily in the institution to make a great effort (Nelson \& Quick, 1995).

Commitment is the situation in which a person wants to continue working in the same organization with the ideas of friendship, order, retirement plans, without thinking of finding a new job in the organization where the person is working for years (Greenberg and Baron, 1996).

Normative commitment can also be called moral commitment. Normative commitment refers to the perceived obligation to remain in the organization. Employees feel the sense of duty and obligation to stay in the organization and develop a compulsory commitment. It has been reported in several studies that normative commitment is related to employees' personal loyalty norms (Allen, Meyer \& John, 1990).

\section{Research Model}

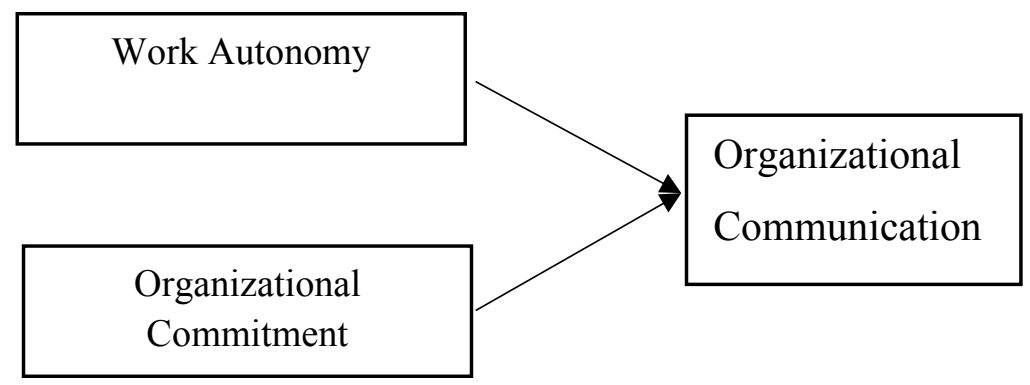

Figure 1. Research Model

\section{Methodology}

Statistics

The survey data was analysed using SPSS for Windows 22.00 and AMOS 22.0 software. Confirmatory factor analysis (CFA) of the scales included in the research questionnaire was performed and Cronbach Alpha values were calculated. In addition, correlation and regression analysis were applied to the sub-dimensions obtained in the factor analysis. 
In order to collect data, the following three scales were used: (1) the organizational communication scale proposed by Bakar and Mustaffa (2013), (2) organizational commitment scale used by Aydan Yüceler, and (3) the work autonomy studied by Ilardi, Leone, Kasser \& Ryan (1993).

\section{Analyses and Results}

\section{Demographic Features}

The survey conducted in the health sector, was a questionnaire administered to 171 employees. The collected data of 11 questionnaires was not enough to be evaluated so 11 employees were excluded from the evaluation. Therefore, the number of participants is 160 .

Table 1. Percentage Distribution of the Demographic Characteristics of the Participants

\begin{tabular}{|c|c|c|c|c|c|}
\hline & & $\%$ & & & $\%$ \\
\hline \multirow{2}{*}{ Gender } & Male & $41.2 \%$ & \multirow{4}{*}{ Job } & Doctor & $6.9 \%$ \\
\hline & Female & $58.8 \%$ & & Nurse & $23.8 \%$ \\
\hline \multirow{4}{*}{ Age } & Between $20-25$ years & $41.9 \%$ & & Technician & $26.2 \%$ \\
\hline & Between 26-30 years & $30.0 \%$ & & Other & $43.1 \%$ \\
\hline & Between $31-35$ years & $23.1 \%$ & \multirow{6}{*}{ Experience } & Less than 1 year & $13.1 \%$ \\
\hline & More than 41 years & $5.0 \%$ & & Between 1-5 years & $36.2 \%$ \\
\hline \multirow{4}{*}{ Education } & Primary School & $6.2 \%$ & & Between 5-10 years & $34.4 \%$ \\
\hline & High School & $43.8 \%$ & & More than 10 years & $16.2 \%$ \\
\hline & University & $46.2 \%$ & & & \\
\hline & MS/Ph.D & $3.8 \%$ & & & \\
\hline
\end{tabular}

\section{Reliability}

The validity of a scale refers to the extent to which that scale measures the variable it wants to measure. Validity tests are done by theoretical analysis.

Table 2. Reliability of Research Scales

\begin{tabular}{lcc}
\hline Scale & Number of Items & Cronbach's Alpha \\
\hline Work Autonomy (WA) & 4 & .820 \\
Organizational Communication (COM) & 9 & .917 \\
Organizational Commitment (OC) & 11 & .898 \\
$\quad$ Normative Commitment (NC) & 5 & .783 \\
Continuance Commitment (CC) & 3 & .743 \\
Affective Commitment (AC) & 3 & .872 \\
\hline
\end{tabular}

It is understood that Organizational Communication (.917) and Organizational Commitment scales are at high reliability level $(>.80)$. In the sub-dimensions of the Organizational Commitment scale, it is seen that the reliability values obtained in 5-item normative commitment dimension (.783) and 3-item Continuance Commitment dimension (.743) are in a highly reliable scale with 3-item Affective commitment dimension (.872).

Confirmatory Factor Analysis (CFA) of Work Autonomy (WA) Scale

Out of seven items of work autonomy scale, three of them were eliminated because the factor loads were low. Factor weight values $(0.50 ; 0.92)$ in CFA with the remaining 4 items were in the range. 


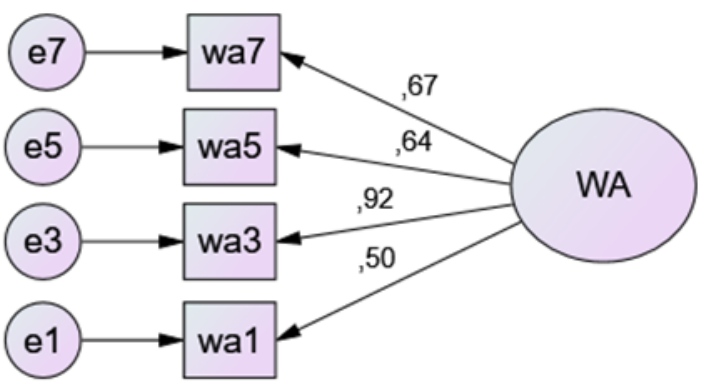

Figure 2. Confirmatory Factor Analysis of Work-Autonomy (WA) Scale

In the confirmatory factor analysis, CFA was found to be significant because the model test values were $\boldsymbol{x}^{2}$ (3.275) and $\boldsymbol{x}^{2} / \boldsymbol{d} \boldsymbol{f}$ (1.638). In addition, the fit index values GFI (.989), CFI (.993), SRMR (.0268), RMSEA (.063) were found to be within the acceptable limits. CFA result was acceptable (Bollen, 1989).

\section{Confirmatory Factor Analysis Organizational Communication (COM) Scale}

Factor weight values $(0.630 ; 0.92)$ were obtained from organizational communication scale, to factor analysis.

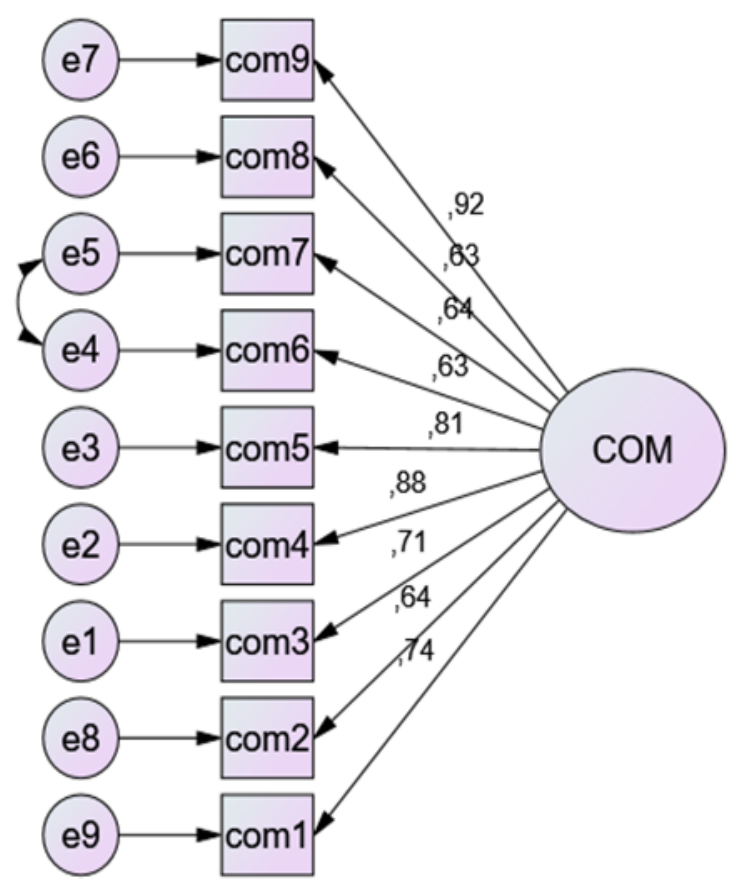

Figure 3. Confirmatory Factor Analysis of Organizational Communication (COM) Scale

In confirmatory factor analysis, CFA was found to be meaningful because the model test values were $\boldsymbol{x}^{2}$ (39.432), $\boldsymbol{x}^{2} / \boldsymbol{d} \boldsymbol{f}$ (1.972). Further, the fit index values GFI (.949), CFI (.979), SRMR (.0459), RMSEA (.078) were found to be within acceptable limits. 
Confirmatory Factor Analysis of Organizational Commitment (OC) Scale

Nine items of the twenty items Organizational Commitment (OC) were eliminated because the factor loadings were low. The item factor's weight values $(0.51 ; 0.92)$ in the CFA with the remaining 11 items were in the range.

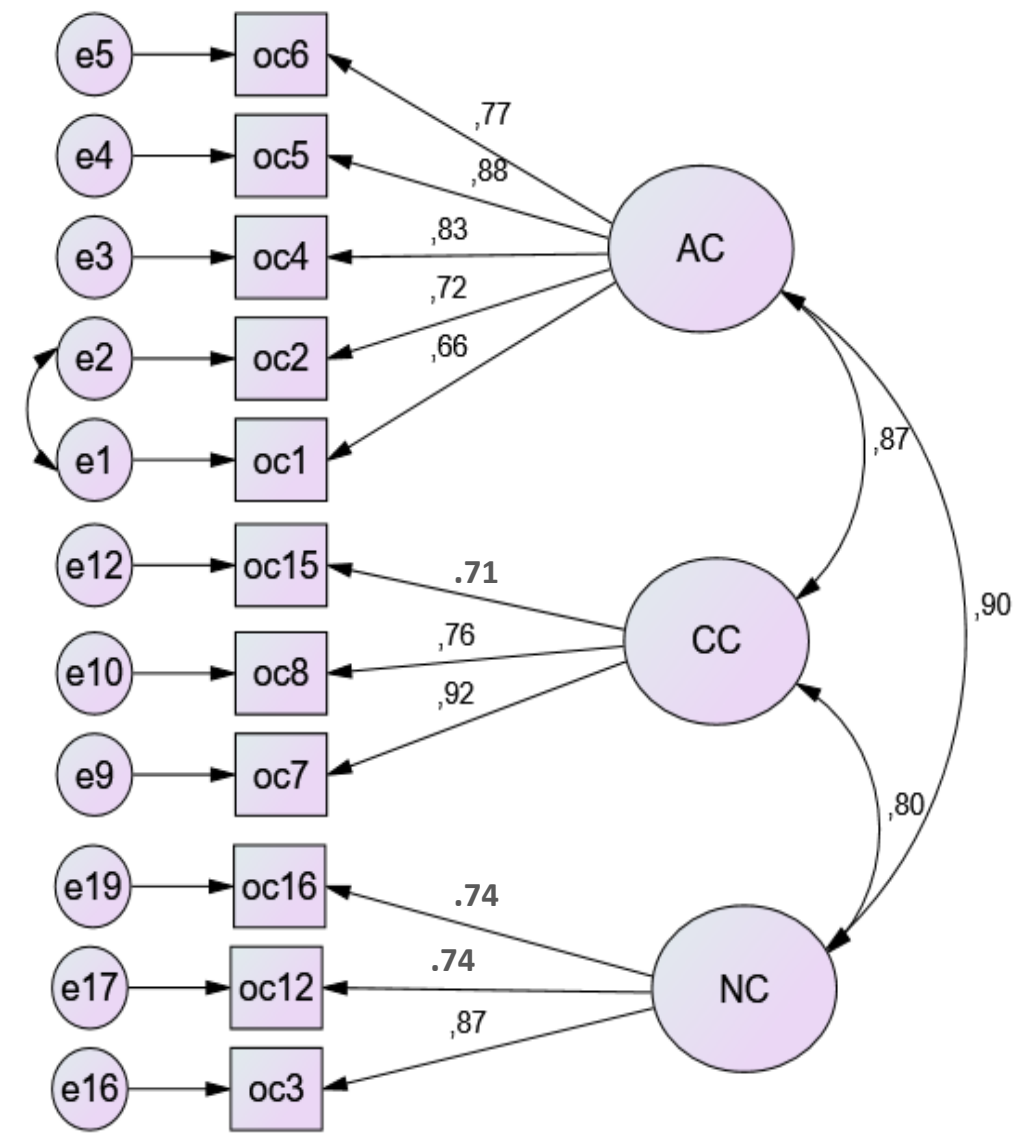

Figure 4. Confirmatory Factor Analysis of Organizational Commitment Scale

In the confirmatory factor analysis, DFA was found to be significant because the model test values were $\boldsymbol{x}^{2}$ (55.226), $\boldsymbol{x}^{2} / \boldsymbol{d} \boldsymbol{f}$ (1.904). Further, the fit index values GFI (.940), CFI (.978), SRMR (.0486), RMSEA (.0750) were found to be within acceptable limits.

\section{Path Analysis of the Model with Structural Equation Modelling}

In order to investigate the predicted relationships with hypotheses, a path diagram was drawn with the AMOS 22.0 package program and the Maximum Likelihood method was used to estimate the structural parameters. Path diagrams of the models are given as figures. The AMOS SEM program gives the results of the analysis separately as standardized and non-standardized coefficients. In this analysis, standardized coefficients were used for intelligibility. 
Table 3. Regression Parameters Obtained From the Model and Structural Equations

\begin{tabular}{|c|c|c|c|c|c|c|}
\hline Affecting & Effect & Affected & $\begin{array}{l}\text { Non-standardized } \\
\text { coefficients }\end{array}$ & $\begin{array}{l}\text { Standardized } \\
\text { coefficients }\end{array}$ & CR & $\mathbf{P}$ \\
\hline $\begin{array}{l}\text { Organizational } \\
\text { Commitment (OC) }\end{array}$ & $\rightarrow$ & Work Autonomy (WA) & .791 & .556 & 5.457 & $* * *$ \\
\hline $\begin{array}{l}\text { Organizational } \\
\text { Commitment (OC) }\end{array}$ & $\rightarrow$ & $\begin{array}{l}\text { Organizational } \\
\text { Communication }(\mathrm{COM})\end{array}$ & -.392 & -.234 & -2.230 & $*$ \\
\hline \multicolumn{4}{|l|}{ Structural Equation } & & \multicolumn{2}{|l|}{$\mathrm{R}^{2}$} \\
\hline \multicolumn{4}{|c|}{ Organizational Communication $=-0.23 * \mathrm{OC}-0.31 * \mathrm{WA}$} & & \multicolumn{2}{|l|}{$26 \%$} \\
\hline \multicolumn{4}{|c|}{ Work Autonomy $(\mathrm{WA})=0.56^{*} \mathrm{OC}$} & & \multicolumn{2}{|l|}{$52 \%$} \\
\hline \multicolumn{7}{|c|}{$\begin{array}{l}\text { WA: Work Autonomy, COM: Organizational Communication, OC: Organizational Commitment, NC: Normative } \\
\text { Commitment, CC: Continuance Commitment, AC: Affective Commitment }\end{array}$} \\
\hline
\end{tabular}

In the model, the Work Autonomy (WA) variable positively affects the Organizational Commitment (OC) variable (0.56). It is understood that the increase in the Organizational Commitment (OC) and Work Autonomy (WA) variables increases the Work Autonomy (WA) variable. In this model, Work Autonomy (WA) variable is explained from $52 \%$.

In the model, the Organizational Communication (COM) variable, the Organizational Commitment (OC) variable (-0.23), adversely affects the inverse and Work Autonomy (WA) (-.31) variable. It is understood that the increase in the Organizational Commitment (OC) and Work Autonomy (WA) variables will affect the Organizational Communication (COM) variable. In this model, Organizational Communication (COM) variable is explained by 26\% (Fornell and Larcker, 1981; Schermelleh-Engel, Moosbrugger \& Müller, 2003).

\section{Conclusion}

In this research, a data collection questionnaire was created by using work autonomy, organizational communication and organizational commitment scales. Reliability analyses and confirmatory factor analyses were performed for each scale. Furthure, the statistical analysis of the collected data was conducted and the connections between the relations with the structural equation model obtained.

The current study, investigated the impact of work autonomy and organizational commitment on organizational communication by considering the perceptions of health employees. As a result of the applied structural equation model, work autonomy variable affects the organizational commitment variable positively. It is understood that the increase in the organizational commitment and work autonomy variables affect the increase of the work autonomy variable.

In this model, work autonomy variable can be explained by $52 \%$ and organizational communication variable by $26 \%$. In the designed model, Organizational Communication variable adversely affects the organizational commitment variable and work autonomy variable adversely affects it. The increase in the organizational commitment and work autonomy variables affect the organizational communication variable.

\section{References}

Allen, N. J. \& Meyer, J. P. (1990). The measurement and antecedents of affective, continuance and normative commitment to the organization. Journal of occupational psychology, 63(1), 1-18.

Bakar, H. A. \& Mustaffa, C. S. (2013). Organizational communication in Malaysia organizations: Incorporating cultural values in communication scale. Corporate Communications: An International Journal, 18(1), 87-109.

Bollen, K. A. (1989). Structural equations with latent variables Wiley. New York. 
Brewer, A. M. (1996). Developing commitment between managers and employees. Journal of managerial psychology, $11(4), 24-34$.

Brey, P. (1999). Worker autonomy and the drama of digital networks in organizations. Journal of Business Ethics, 22(1), 1525 .

Davis, K. A. (1994). Sport management: successful private sector business strategies. Brown \& Benchmark.Davis, K., \& Newstrom, J. W. (1989). Human behavior at work: Organizational behavior.

Dee, J. R., Henkin, A. B. \& Chen, J. H. H. (2000). Faculty autonomy: perspectives from Taiwan. Higher Education, 40(2), 203-216.

Fornell, C. \& Larcker, D. F. (1981). Evaluating structural equation models with unobservable variables and measurement error. Journal of marketing research, 18(1), 39-50.

Gellatly, I. R. \& Irving, P. G. (2001). Personality, autonomy, and contextual performance of managers. Human performance, 14(3), 231-245.

Hackman, J. R. \& Oldham, G. R. (1976). Motivation through the design of work: Test of a theory. Organizational behavior and human performance, 16(2), 250-279.

Ilardi, B. C., Leone, D., Kasser, T. \& Ryan, R. M. (1993). Employee and supervisor ratings of motivation: Main effects and discrepancies associated with job satisfaction and adjustment in a factory setting 1. Journal of Applied Social Psychology, 23(21), 1789-1805.

Greenberg, J. \& Baron, R.A. (1996). Behaviour in Organizations, 6th edition, ISBN-13: 978-0135217252, ISBN-10: 3034601646, Prentice Hall College.

Koçel, T. (2001). İşletme yöneticiliği, yönetim ve organizasyon, organizasyonlarda davranış klasik-modern-çağdaş ve güncel yaklaşımlar. 8. Ístanbul: Beta.

Leong, C. S., Furnham, A. \& Cooper, C. L. (1996). The moderating effect of organizational commitment on the occupational stress outcome relationship. Human relations, 49(10), 1345-1363.

Morgeson, F. P., Delaney-Klinger, K. \& Hemingway, M. A. (2005). The importance of job autonomy, cognitive ability, and job-related skill for predicting role breadth and job performance. Journal of applied psychology, 90(2), 399.

Morris, T., Lydka, H. \& O'Creevy, M. F. (1993). Can commitment be managed? A longitudinal analysis of employee commitment and human resource policies. Human Resource Management Journal, 3(3), 21-42.

Morrow, P. C. \& McElroy, J. C. (1986). On assessing measures of work commitment. Journal of Occupational Behaviour, $7(2), 139-145$

Nelson, D. \& Quick, J. C. (1995). Organizational Behaviour: Foundations, Realities and Challenges, USA: West Publishing.

Md Nordin, S., Halib, M. \& Ghazali, Z. (2011). Strengthening internal communication: A case of communication satisfaction in an organization. European Journal of Social Sciences, 24(4), 617-624.

Saragih, S. (2015). The effects of job autonomy on work outcomes: Self efficacy as an intervening variable. International Research Journal of Business Studies, 4(3).

Schermelleh-Engel, K., Moosbrugger, H. \& Müller, H. (2003). Evaluating the fit of structural equation models: Tests of significance and descriptive goodness-of-fit measures. Methods of psychological research online, 8(2), 23-74.

Schwalbe, M. L. (1985). Autonomy in work and self-esteem. Sociological Quarterly, 26(4), 519-535.

Speetor, E.Paul. (1996), Industrial and Organizational Psychology, John. Wiley and Sons inc.,New York.

Vansteenkiste, M., Simons, J., Lens, W., Sheldon, K. M., \& Deci, E. L. (2004). Motivating learning, performance, and persistence: the synergistic effects of intrinsic goal contents and autonomy-supportive contexts. Journal of personality and social psychology, 87(2), 246.

Yatkın, A. \& Yatkın, Ü. N. (2010). Halkla İlişkiler ve İletişim, Nobel Yayın Dağıtım, 3. Baskı, Ankara. 